\title{
Distancing Gender in Contemporary Hungarian Fiction
}

\section{Pál Hegyi}

\begin{abstract}
Representations of gender crossing go back to a rich tradition in Hungarian literature. The most conspicuous achievements for performing gender passing on the authorial plane are epitomized in such fictionalized female literary alter egos as Erzsébet Lónyay (Sándor Weöres), Lili Csokonai (Péter Esterházy), and Jolán Sárbogárdi (Lajos Parti Nagy). Providing a unique sensibility to seek out innovative forms that could accommodate interrogations into distancing gender, it is a legacy that finds continuation in the works of a new generation of young Hungarian prose writers. By conducting closereadings of literary pieces by two present-day writers, Pál Hegyi's paper endeavors to give instances of how gender passing is transposed from the authorial plane to the level of narratives. The short stories "Karambol" ['Crash'] by Ádám Berta and "Pertu” ['On Intimate Terms'] by Edina Szvoren will be interpreted to adumbrate distancing narrative strategies for crossing gender boundaries.
\end{abstract}

Keywords: literary pseudonyms, gender crossing, gender distancing, contemporary Hungarian fiction, Ádám Berta, Edina Szvoren

Biography: Pál Hegyi (PhD) is Senior Assistant Professor at the Department of American Studies, Eötvös Loránd University. He has published on interpretation theories, contemporary American and Hungarian literature, narratology, and popular culture. Hegyi is the author of numerous studies and reviews published both in Hungarian and international journals (Filológiai Közlöny, Literatura, Americana, Hungarian Review; Hungarian Cultural Studies). As literary translator, he has novels of Elmore Leonard, Stephen King, and David Cronenberg to his name. His monograph delineating the uncanny nature of absence in Paul Auster's early work was released in 2016 (Fehér terek ['White Spaces']), while his second volume on the memetic allegorizations of the uncanny (Lovecraft Laughing: Uncanny Memes in the Weird) has been published this year by AMERICANA eBooks. hegyi.pal@btk.elte.hu

Clearly defined boundaries between modernist, postmodernist sensibilities and contemporary modalities in the aftermath of those epistemes are still under construction in present-day literary criticism. Innovations in poetics, rhetoricity, meaning and form are disparate to the extent that it appears to motivate research restricted to specific literary phenomena. Through different approaches of deconstructing fixed gendered authorial identities, the present paper sets out to hypothesize a gradual shift towards a stage where subversion is directed at characters, narrators, and signifying processes. Whereas a high modernist tendency to create unity through Sándor Weöres's imitation will be put in contrast with Péter Esterházy's postmodernist simulation and, finally, Lajos Parti Nagy's dissemination as strategies to undermine gendered binaries, three close-readings of contemporary Hungarian fiction will 
showcase distinctly different formations in poetics. Despite easily identifiable biographical parallels, in these instances the concept of preexisting gendered essence is made impossible by various identity splits, collisions and transgressions that are being performed in the narratives. As signifiers, Ádám Berta's biographical reference to a trip to Bruges or Edina Szvoren's protagonist of similarly distant Slovakian origin are rendered meaningless, empty and without referent by strategies to deconstruct signification, corporeality, and rhetoricity respectively. With contrast to the legacy of authorial role-playing games, the interpretations in this article attempt to corroborate that these narrative innovations dislocate the deconstruction of essences from gendered binaries by way of "distancing gender" on the level of narratives.

First, to clarify how "distancing gender" emerged in certain contemporary Hungarian narratives as a response to fictional cross-gendering in modernist and postmodernist literary modes, a short introduction of the term and its history is necessary. When addressing the problem of gendered identities being performed in prose, Robyn R. Warhol establishes a distinction between female and male forms of narrations in her book Gendered Intervention. According to Warhol, an effect of indirect connectivity between a work of fiction and the reader is what creates a capacity for performative acts of identification and subjectivation within the domain of narratives.

Having negotiated Jonathan Culler's frequently quoted question, i.e., "What would it be to read 'as a woman'?" (Culler 1983: 63), Warhol's interrogation inevitably leads to a second inquiry. Her book centers on a distinction between the biographical author and the implied reader when describing the aesthetic potential in gendered identity games. Warhol's binary opens up to gender shifts in the intersection of male and female technologies of writing: "My analysis of novels that don't fit the model of feminine-gendered engaging interventions and masculinegendered distancing interventions shows how novelists could, if only momentarily, 'cross dress,' usually for specific rhetorical purposes" (Warhol 1989: 18) The central term of "distance" in my research is extrapolated to a narratology of gendered physical bodies and discursive identity constructions inasmuch as the introduction of this concept relativizes where one sex or self begins, and the other ends. In other words, subversion of fixed gendered positions results in upsetting the hierarchy of marked and unmarked elements in the polarity. A transient stage in signification and meaning production within the narrative framework gains a unique potential for performing gendered identity constructions unconstrained by fixed male or female positions in "distancing gender."

The term is deployed in this investigation to delineate an observable shift from modernist, postmodernist tendencies to play out cross-gendering on the authorial plane towards present-day literary efforts to relegate such identity games to the level of narratives. Works by Erzsébet Lónyay (Sándor Weöres), Lili Csokonai (Péter Esterházy), and Jolán Sárbogárdi (Lajos Parti Nagy) will be contrasted with three contemporary short stories, which, as opposed to gendered role-playing games, will showcase differing strategies for distancing gender as a narrative device.

\section{The Legacy of Role-Playing Games in Hungarian Literature: Weöres, Esterházy, Parti Nagy}

Literary pen names are often used as an artifice, a form of camouflage that then discloses the inherently fictitious nature of the readers' conception of the authorial persona. One of the most peculiar characteristics of Hungarian literature is that it features an ongoing tradition of male authors masking themselves behind fictional female identities. Without exception, these 
Hegyi, Pál. "Distancing Gender in Contemporary Hungarian Fiction.” Hungarian Cultural Studies. e-Journal of the American Hungarian Educators Association, Volume 12 (2019) DOI: 10.5195/ahea.2019.363

authors had already been widely published and successful at the time of their textual 'crossdressing;' still, in two of these cases, a certain period of time passed before their true identities were revealed. Hence, choosing a pen name as a strategy to trick the gatekeepers of high culture and thereby enter the canon - as occurred in the cases of the nineteenth-century authors, George Sand or George Eliot - was clearly not the motivation for partaking in such identity games. One could argue that a guessing game of this kind, a puzzle to be solved, or the mystery in itself is but a marketing scheme to reach the audience; however, the mastery with which these literary monuments were erected was a guarantee for success in itself.

Narrative gender switches or authorial role-playing games in the modernist, postmodernist epistemes of Hungarian literature are geared toward what I label as distancing gender on the authorial plane. By interchanging the marked and unmarked poles of patriarchal gender codes, a domain of suspended essentialist gender identities is being created. In such a domain, distancing gender generates an opportunity for subverting, disrupting and reiterating fixed gender codes. In the first instance provided by the Hungarian literary canon, distancing gender is played out in an idealized past that is hypothetically free of patriarchal power structures. The extension of an alternative and utopian cultural history to the present creates a distancing effect from a seemingly transparent and natural economy of genders in the twentiethcentury modernist mode within Hungarian literature.

Not counting the first Hungarian epistolary novel Fanni hagyományai ['The Legacy of Fanni'] by József Kármán (1794), in 1972 it was Sándor Weöres who donned the mask of a female author for the first time in Hungarian literature. The lyrical oeuvre by Weöres is either extolled as a crowning achievement in Hungarian modernist literature, or as a groundbreaking artistic effort toward postmodernism. This tension is already present in the critical reception of his verse-novel Psyché: Egy hajdani költönö írásai ['Psyché: The Writings of a Poetess from the Past'] (1972). The book is a novel in the sense that it is within the framework of an autobiographical narrative, a diary in which poems by Erzsébet Lónyay (Psyché), as well as her lover's verses are embedded. A fictitious woman poet from the early nineteenth century, Psyché's border-crossings through geographic, political, and gendered spaces would not have been possible in patriarchal nineteenth-century Hungary. Critics of the day heavily attacked her spontaneous travels, libertarian antics and sexual indecencies were heavily attacked for their anachronistic nature. The contradiction lay in the fact that Weöres, a virtuoso of form, language and versification, created a flawless and impeccable imitation of the lyrical tradition of the period. Yet, it is exactly this quality of the verse-novel that generates the potential for performing a gendered identity with agency. When contrasted with the authenticity of language and art form, an anachronistic subversion of patriarchal gender scripts is being played out in readings of the book. Putting on the mask of a non-existent woman poet from the nineteenth-century is itself a paradox made possible only through retrospective empowerment. Such a heroine could not have been real for the reason that women authors were not canonized within the social-political power structures of Hungary at that time. Erzsébet Lónyay is brought into existence to dismantle such hierarchies. To elucidate the exact nature of gender passing in Psyché, my interpretation needs to adopt a term coined by Enikö Bollobás in her compelling book, They Aren't Until I Call Them (2010). "Passing can be described either as full passing, which is always performance, or play passing, which is the interrogation and subversion of the binary system and, as such, is always the performative creation of new ontologies" [emphasis added] (Bollobás 2010: 17). In Pysché's case gender-crossing on the authorial plane is utilized as play passing to perform the seeing, 
Hegyi, Pál. "Distancing Gender in Contemporary Hungarian Fiction.” Hungarian Cultural Studies. e-Journal of the American Hungarian Educators Association, Volume 12 (2019) DOI: 10.5195/ahea.2019.363

hearing subject in the past and, by extension, to perform gender identities with agency at present, in the here and now.

If inauthenticity, inconsistency, and anachronism were attributes for which scholars levelled their criticism against Psyché, the very same qualities were purportedly retailored into the constitutive elements of postmodern poetics in Péter Esterházy's Tizenhét hattyúk ['Seventeen Swans']. Here, distancing gender is relegated to the rhetorical dimension of the text, in which irony and the simulation of fixed gender codes erase patriarchal power structures. The tragic love story of Lili Csokonai, a woman born in 1965, is narrated throughout the seventeen chapters (i.e., the seventeen swans) in a Baroque style with the kind of eloquence and vocabulary that is reminiscent of an era three hundred years before. Yet, mimicry and imitation is assiduously being corrupted. The time is the present and the scene is banal and ordinary. After losing her parents, the protagonist moves to her uncle's, then falls in love with Márton Kéri. After a car accident in which Lili loses her legs, Márton abandons her heartlessly, for which Lili murders him in the end. The elevated style and archaic state of language is incessantly disrupted by the irruption of present-day phenomena and paraphernalia, for instance, the car, which is described as "his locomoting Devil's Chariot (Volkswagen)" [ennenmozgó ördeghintaja (Volkswagen)] (Esterházy 1987: 5). In the nonmimetic, non-referential textuality of Esterházy's novel, it is language itself that is placed in the center creating a self-contained simulacrum instead of the mimesis of language, space and time. The distance between radical language games and the reality of the reader, the remove of the authorial figure by inserting the mask of Lili Csokonai in between reader and writer generates a transitory, gendered space. Simulation and irony undermine the fixed position of the female protagonist as the object of male desire, thus opening a gateway to shifting gender identities.

In the previous instances, distancing gender formations was first made possible through imitation (Psyché), then by simulation (Seventeen Swans). In 1997, Lajos Parti Nagy, a representative of the second wave of postmodernist writers in Hungary, published a work of pseudo pulp fiction. Distancing gender in Parti Nagy's novel is played out to the effect that the radical irony which permeates the deepest structural layers of the text questions the existence of any boundaries that could separate the opposing poles of patriarchal gender binaries. Released under the name of Jolán Sárbogárdi, A test angyala ['The Angel of the Body'] brought to its terminal point the distancing gender on the authorial plane, that is, to dissemination. Sárbogárdi — an assonance with Charles Bovary - is a dilettante, a fervent reader of romances and girl novels, who desires to live her life as if it were art. Determined to have her first literary effort published, she sends her manuscript to one of Hungary's most prominent literary critics, Péter Balassa, who accepts and praises her work in his prompt reply for its "benign deconstructionism" [jótékony dekonstrukció] (Balassa 1990: 525). Indeed, the plot sequence is motivated only by predictable romantic sagas and compulsory happy endings. Boy (Dénes Balajthy) meets girl (Jolán Sárbogárdi), they instantly fall for each other and, after some misunderstandings, the couple is finally reunited in marital happiness. The style and discourse is hilariously humorous, for the entire text is swarming with basic spelling errors, hypercorrections, redundancies, mixed metaphors, truncated sentences, dangling clauses and tired clichés while the amateurish author mixes formal and informal styles in every possible way. Lajos Parti Nagy has never published this work under his own name; the oscillation between male author and female alter ego is projected and disseminated to the level of the discourse. An exquisite piece of literature that disguises itself 
as the early effort of a snobbish amateur instantly raises the question: who is speaking? Is it the female author, an obvious victim of popular fiction, expected norms, and consumer society, or rather, is it the male author, who turns her romance into a Swiftian satire on the human condition? As an empty reference to the medieval concept of "corpus angelicus," the title suggests that all gender positions remain undecidable. As persiflage, pastiche and parody, the text of Jolán Sárbogárdi (Charles Bovary) is neither a performative act creating a gendered identity, nor a performance of normative scripts, but rather a chaotic, free play of floating signifiers. The experience of cross-dressing remains androgynous within the inexhaustible territory of language games conducted via mixed metaphors and tired clichés. The fact that Edina is sometimes referred to as Enikö, and other times as Emese, underscores the lack of her fixed identity position. All boundaries are blurred and portend the impossibility of being crossed. From the authorial plane, The Angel of the Body relegates gender crossing to the level of narratives, thus paving the way towards the narrative innovations highlighted in the short stories of three authors belonging to the next generation of writers in Hungarian literary tradition.

\section{Catachrestic Gender Switch: Distancing Gender in Ádám Berta's "Crash"}

Distancing gender on the authorial plane in twenty-first-century Hungarian prose writing has been transformed from the previously examined role-playing games to narrative devices in the three short stories offered for analysis below. In the first instance to be scrutinized here, the domain for gender relativization is created at the level of signification, that is, in catachrestic tropes for gendered identities. A representative of a fashionably prolific new generation of Hungarian prose writers, Ádám Berta is especially noted for his arresting experiments in narrative form and structure. Berta's approach toward uncharted capacities in language results in unexpected turns with each of his newly published short stories and novels. An acclaimed literary translator and editor for major publishing companies who also holds a $\mathrm{PhD}$ in literary studies, Berta is not only well-informed on literary trends and accompanying theoretical considerations, but consciously draws upon them in his art. Published in 2015, his short story, "Karambol" ['Crash'], is a poignant example of how the conflict of gendered polarities can be negotiated in a radically different mode within the sub-text of any narrative. Irrespective of the given gender context, binaries of marked and unmarked gender inflections emerge as distinctive elements when deployed as topics on the authorial plane. In the instances discussed above, the prominent questions raised by the practice of play passing were directed toward the identity and the gender of the author, implied reader, narrator, or autobiographical writer. In the books created by the Weöres/Lónyay, Esterházy/Csokonai, and Parti Nagy/Sárbogárdi authorial constructions, the context was offered by wielding masks and engaging in role-playing games which, in turn, generated the narrative potential for comments on the very nature of gendered identities. However, in Berta's text, gendered differences are relegated to the level of signifying processes, to the semiotic dimension of the text.

The one-page-long short story of "Crash" entails two seemingly disparate sequences of events. Both of these are built around protagonists whose gender is initially not unveiled to the reader as the first-person singular accounts given by both narrators do not reveal genders. The initial storyline features a generic speaker in the first three paragraphs, an everyday person who recounts the minimalistic experience of arriving at work in Bruges early in the morning. It is only when looking into a mirror that the corporeality of the Groeningemuseum salesperson at the gift shop is revealed in the reflection of a curly-haired, big-boned, lonely, middle-aged woman 
Hegyi, Pál. "Distancing Gender in Contemporary Hungarian Fiction.” Hungarian Cultural Studies. e-Journal of the American Hungarian Educators Association, Volume 12 (2019) DOI: 10.5195/ahea.2019.363

fearing the inevitable liver spots that coming with age: "A curly-haired woman, that's what I am" [Göndör hajú nö, ez vagyok] (Berta 2015: 33). (All translations of Ádám Berta are by Lina Mounzer.) The remaining nine paragraphs tell the story of an accident, in the course of which a horse drawing a carriage in Bruges crashes into a tourist from Pécs. Without making any specific reference to the second narrator's gender, the narrative states that this person bought a coloring book in the Groeningemuseum gift shop for a relative. The reader is informed that the crash was the direct consequence of the misfortune that one of the handles of the plastic bag in which the gift was placed broke, and so, the book fell to the ground, prompting the speaker to bend to pick it up. This singular action as chance event in the plot is paralleled in the final lines, where the same narrator glimpses somebody whose grasp loosens from the one remaining handle of a bag. This character is revealed to be a man, but he has a bike and goods other than a coloring book in his bag (a beer can, a sweater, and a soap dispenser). Thus, the reader may or may not surmisebased on indirect textual evidence - that the second narrator might be man.

The gender of the second narrator as male is revealed only retrospectively in the penultimate paragraph, when, as mentioned above, while watching two men the tourist notices that one "held only one handle of the bag, and then suddenly it slipped out of his grasp" [az egyik fülét fogta a zacskónak, aztán leejtette] (Berta 2015: 33). The index of the broken handle defers signification by way of referencing a Doppelgänger or double, since the content of the bag belonging to the alter ego is not the coloring book bought by the narrator but miscellaneous goods (beer, sweater, soap). The effect of disrupting referential polarities of signification is further corroborated by an insertion of a hallucinatory sequence after the crash in the narrative. This section does not offer a story within the story, but rather foregrounds the transference of all indices, attributes from narrator number one (the shopkeeper) to the second narrator (the tourist). "Several hallucinations had passed through my mind in that period of time between being kicked by the horse and coming to. They were simple things, but all the more realistic for being so. I felt I was alone. I imagined myself to be a big, curly-haired woman. That's what I am, I thought. Big, curly-haired. I don't even need ten years to become explicitly, decidedly fat. And my hand is liver-spotted" [Sok mindent hallucináltam a lórúgást követö pillanatokban, amíg magamhoz nem tértem. Egyszerü, de annál valóságosabb gondolatok voltak. Úgy éreztem, egyedül vagyok. Nagydarab, göndör hajú nönek képzeltem magam. Ez vagyok, morfondíroztam. Nagydarab, göndör hajú. Már tíz év sem kell, kifejezetten kövér leszek. A kezem pedig májfoltos] (Berta 2015: 33). Here, gender switch is performed on the level of signifying processes at work in the deepstructure of the narrative. The proverbial dark horse serves as a catachrestic trope for the collision of two corporealities and cancels out all polarities of fixed gendered identities. Whereas in the opening paragraph of the story it was impossible to determine the gender of the firstperson singular narrator, the final words of the nameless speaker (first and second narrator crashed into one) are altogether dislocated from such paradigm when contemplating the universal trauma of aging and loneliness in human condition.

A closer scrutiny with regards to the systems of signification at work in the text will disclose that dichotomic constructions of gendered identities are impossible to maintain in "Crash." For the story is about exactly this undecidability; that is, how through the narrator's instable gendered identity it becomes possible for the tourist to visit the other, another gender, another lifeworld. At the level of the discourse, and plot, it is a missed encounter, yet, in the deep structure of the text, they implode ("that's what I am"). In the blind spot of the text the reader finds a work of art embedded within the story, a painting the relevance of which will be made clear below. One particular picture by Gerard David in the Groeningemuseum will thematize the 
Hegyi, Pál. "Distancing Gender in Contemporary Hungarian Fiction.” Hungarian Cultural Studies. e-Journal of the American Hungarian Educators Association, Volume 12 (2019) DOI: 10.5195/ahea.2019.363

delayering of corporeality as a central trope for the text, thus creating a distance from bodily existence, which will make it possible to contemplate aging and mortality regardless of gender in the narrative.

Although the two storylines are kept separate throughout the narration, at first glance, they are continuously interlinked with Barthesian hermeneutic codes indicating toward an enigma (Barthes 1974: 42). In S/Z Roland Barthes identifies five different codes that he defines as instrumental in establishing the realism of a text. Among these, the hermeneutic code functions as the voice of truth responsible for the disclosure of a secret. In "Crash," tropes, references, indices lead the reader towards genre expectations (of a romance, or mystery), towards a possible solution, resolution, and closure. One could easily be tempted to create poststructuralist interpretations putting dissemination, cancellation of meaning and ever-present language games into focus not dissimilar to analyses conducted in the case of, as was summarized above, A test angyala ['The Angel of the Body'] by Lajos Parti Nagy. Indeed, apart from the broken handles of two different plastic bags and the doubled scene of self-mirroringboth of which fail to create meaning or fulfil any promise for a resolution - the text is crammed with codes that hint at a puzzle. The shopkeeper imagines how being a tourist - that is, the second narrator - might deconstruct contextual meaning when only seeing a snail absurdly carrying a backpack where there is a traffic sign to warn drivers to slow down near the school. Narrator number two observes the presence of a pregnant woman next to an old man clutching a cane between his legs, possibly a code signaling the success or failure of a romance. The image of a horse as an archetypical symbol for the sexual instinct on the front of a postcard chanced upon in the gift shop might also serve as a prefiguration of romantic desire (never) to be fulfilled. However, these patterns would presuppose binary modes of signification between antecedent and proform, identifier and identified, tenor and vehicle, signifier and signified. At the level of the discourse, the two narratives running parallel do appear to be in binary opposition, thus foreshadowing either conflict or reconciliation in their progression. Yet, when having encountered the first narrator during one single occasion, narrator number two leaves the shop; his state of mind is described with words reminiscent of Dickinsonian sentiments: "I was bathed in a blinding ray of slanted sunshine" [A boltajtón kilépve vakitó, rézsútos fény fürdetett] (Berta 2015: 33). The Hungarian original for "slanted" light [rézsútos] is hardly ever present as a subordinate adjective in noun phrases that have "fény" [light] as their heads in Hungarian except for translations of Emily Dickinson's poetry (Bollobás 2015: 33, 101, 160, 166). Bollobás identifies the poet's metaphor of "slant of light" as poignant description of catachresis in the Dickinsonian oeuvre (Bollobás 2012). Bollobás contends that catachresis as pure nonreferentiality - containing a vehicle stripped of its tenor - is troping the unthought, the unknowable, the unthinkable (Bollobás 2012: 51). Also, a figure of speech signifying undecidabilities (Bollobás 2012: 25), catachresis in Bollobás's theory is deployed as a figural instrument to perform new gender scripts in the proto-modernist poetry of the American author (Bollobás 2012: 37ff).

It is exactly this catachrestic "blinding ray of slanted sunshine" [vakitó, rézsútos fény] (Berta 2015: 33) that is instrumental in deconstructing any metaphorical reading of the plot in Berta's short fiction. The story is framed by the initial and final scenes of a bridge opening up, the crossing of which creates the possibility for the chance event of the crash in front of the museum gift shop. If both the gateway and the collision were metaphors, the traditional sequence in the metanarrative of a romance could be completed within such binary systems of signification. The tourist's fixed male identity would engage in an encounter with the female 
Hegyi, Pál. "Distancing Gender in Contemporary Hungarian Fiction.” Hungarian Cultural Studies. e-Journal of the American Hungarian Educators Association, Volume 12 (2019) DOI: 10.5195/ahea.2019.363

shopkeeper by having crossed cultural (Hungarian vs. Flemish, tourist vs. native) boundaries. However, the inapplicability of such metaphorical interpretation is already emphasized by the fact that the purpose of visiting the Groeningemuseum for narrator number one was to find Gerard David's painting The Judgment of Cambyses. "I recalled that here I would find exhibited the Gerard David painting, The Judgement of Cambyses. A few days ago I had come across it on the internet by googling the word 'flaying"' [Eszembe jutott, itt látható Gerard David festménye, a Cambyse itélete, pár napja bukkantam rá az interneten, miután a nyúzás szót írtam a keresöbe] (Berta 2015: 33).

Delayering or, as it were, flaying gendered corporeality provides the central drama of the text. The uncanny uncertainty of unidentifiable gender constructions is located in the tropological domain of the narrative. The "crash" of two isolated identities is being performed in Berta's short story as a semiotic shift from fixed metaphors in patriarchal symbolic order toward a language outside the binaries of such order. Berta deploys his gender distancing strategy to tell the story of two people, whose encounter becomes possible only after layers of their cultural and gendered identities are flayed. The crash site overlaps with the space of the story, where it is utterly irrelevant to define gendered differences. The first person singular pronoun of the final paragraph is not marked for gender, because it is dislocated from such signifying processes. The closing line, thus, is expressive of the contemplative state of mind of a flâneur losing all identity inflections in aimless wandering: "I was still wandering the streets when night came upon me" [Még akkor is sétáltam, mikor rám esteledett] (Berta 2015: 33).

\section{Modal Detachment-Distancing Gender in Edina Szvoren's “On Intimate Terms"}

A different type of distancing gender will be highlighted in the work of a writer whose fiction reinforces agency by disconnecting fixed subject positions from the narrative by way of shifting the modality of the discourse. The literary output by Edina Szvoren, who graduated as a choral conductor from Franz Liszt Academy of Music, has been awarded more than a dozen distinguished literary prizes, the European Union Prize for Literature of 2015 among them. In 2017, Szvoren was voted Best Author with her Pertu ['On Intimate Terms'] coming in as the second best collection of short stories within the last thirty years in a survey conducted by the emblematic Hungarian literary journal, Jelenkor.

The piece that gives the title of this volume "Pertu" ('On Intimate Terms,' 2009 [Hungarian]/2010 [English]) tells the story of an overnight family gathering. Father and mother arrive from Slovakia to Budapest on New Year's Eve to visit their divorced daughter, who leads a slovenly and solitary life. Her six-year-old son had decided to live with his dad creating a traumatic absence, which permeates the narrative. All characters along with their interpersonal relations are predetermined and unchangeable here. Bodies, detachment, and estrangement are the topics in a discourse that is torn apart by an unbridgeable emotional divide. "Your wife is intolerable, Daddy" [Elviselhetetlen a felesége, apuka] (Szvoren 2010: 16), protests the daughter referring to her own control freak, poisoning mother. There is a ready-made script to be performed in the duration of the visit, a staged performance governed by power structures and a language disrupted by constant silences and compulsive repetitions. The script includes nothing but a ritualistic lamentation regarding how "another year gone by" [Megint eltelt egy év] (Szvoren 2010: 15, 18, 20). For lack of interpersonal relations, this performance - whenever unbearable silence fills the room - is repeatedly initiated by the mother's cue "alright, then" [nakéremszépen] (Szvoren 2010: 16, 18) without success. These failed attempts are expressive of the futility in trying to turn commonplace into rite and habit into intimacy (Szvoren 2010: 20). 
Hegyi, Pál. "Distancing Gender in Contemporary Hungarian Fiction.” Hungarian Cultural Studies. e-Journal of the American Hungarian Educators Association, Volume 12 (2019) DOI: 10.5195/ahea.2019.363

Divides are encoded in the story both in language and corporeality. Mummy speaks and curses in Slovak when she is nervous. Daddy calls "Stone Hill" by its Hungarian name "Köhegy," whereas his wife insists on "Kamenny' vrch" (Szvoren 2010: 15). The daughter with her right-wing political affiliations is reviled as a racist (Szvoren 2010: 18). The father is constantly reminded not to consume any alcoholic drinks by his wife, who keeps gulping down one glass of Lipovina after the other until she finally goes through temper tantrums (Szvoren 2010: 19). Yet, it is the father who is described as a child in several sections (Szvoren 2010: 16, 17), while everybody else is defined in negative terms. Women are "childless mothers" [ $a$ no" gyerek nélküli anya], and mothers are "men without male genitals" [az anya pedig hímivarszerv nélküli férfi] (Szvoren 2010: 20). It is unthinkable that "Mummy too was a child once" [anyuka is volt gyerek] (Szvoren 2010: 17), since all polarities are entangled in a trap set by power relations. In Szvoren's short story, corporeality is dehumanized and controlled by an external power along with the internal trauma and guilt resulting from submission to that very power. As the text dispassionately states, "animals relate to human beings" [állatok vonatkozzanak az. emberekre] with their human-like ugliness (Szvoren 2010: 17). Repulsiveness of bodies as a representation of the guilt in humiliation appears to animate one of the central tropes in the text. The daughter notices "a stray dog lurking by the tennis courts, trailing its dog collar behind it, its feet every now and again becoming entangled in the snare fashioned for its owner's hand" [ $a$ teniszpálya körül ólálkodó gazdátlan kutyát, ahogy a nyakörvét maga után húzza, és lába időnként belegabalyodik a gazda keze számára kialakított hurokba] (Szvoren 2010: 21).

Entanglement in hierarchical binaries overrides and suppresses gendered performances as well. The divorced mother of the six-year-old is deprived of her identity both as a woman and as a mother by being constantly reminded of her childishness. In a script undergirded by patriarchal gendered codes, the domineering mother figure, by taking the position of the unmarked male, would deprive her daughter of all agency in the blame game. However, the source and agent of such accusations is impossible to be located for these are reported in free indirect speech. "What does a mother have to do to make her child choose his father" [Mit kell ahhoz tennie egy anyának, hogy a gyereke az apát válassza] (Szvoren 2010: 16). Authority as dominance and oppression is disseminated on a homogenous surface delimited by external accusations and internal guilt, which are saturating family relations.

The discourse of Szvoren's short story builds up in a way that the topic is reduced to pure absence in distancing alienation, yet the comment is centered on such humanistic values as love, compassion, and presence. In the narrative, language and corporeality become interchangeable, transforming violence and defense into acts of communication. Stinging pain as the violence of absence is indexed by the ever-present spikes mounted on the windowpanes functioning as dove deterrents in the story. Throughout nine pages the reader is presented with the image of spikes cutting into palms, rays of light nine times all together. These spikes signal the presence of an aggressive line of defense between internal and external realities. The resulting cuts and wounds are reminders of the above mentioned humanistic values embodied in the symbol of the dove. Fissures, traumatic wounds also can be detected at the level of discourse in the short story. There is an extra empty seat at the family table "around which on New Year's Eves of old five people used to sit" [ahol régebbi szilvesztereken még öten ültek] (Szvoren 2010: 16). Yet, the missing son is only partially represented here as traumatic absence to which the empty performance (i.e., "another year gone by") is a compulsive return. The son's words of resistance in the telephone ("it doesn't matter now, Mum" [most már mindegy, anya]; Szvoren 2010: 20) changes his commonplace phrase into an obstacle to overcome, something to fight against and fight for. 
Hegyi, Pál. "Distancing Gender in Contemporary Hungarian Fiction.” Hungarian Cultural Studies. e-Journal of the American Hungarian Educators Association, Volume 12 (2019) DOI: 10.5195/ahea.2019.363

Corporal violence is foregrounded as a chance for communication between mother and son, as a possibility to perform their distinct genders and identities. The trope for shifting language into matter, "the dark lake with no surface" [víztükör nélküli sötét tó] (Szvoren 2010: 20-21) in Szvoren's text displays an image of absolute darkness. Without a surface, the darkness at the bottom will inevitably engulf all its surroundings rendering the lake masked in blackness. The existence of the lake precedes its invisibility in the phrase, as the unknown speaker wills it into existence by putting the utterance into the imperative mood: "Let these sentences be the lowest points of that dark lake with no surface" [Ezek a mondatok legyenek annak a víztükör nélküli tónak a legmélyebb pontjai] (Szvoren 2010: 21). Transforming signification into performative actions at the level of the discourse, thus, offers a possibility for the construction of gender and identity in the narrativization of the trauma of absence.

[A] blood relationship is not sufficient to yield a conversation topic, and there would be nothing to talk about if, against her better judgment, she did not ask her son for forgiveness. And let her son not absolve her, let him only say, when he wants very much to get back to bed, it doesn't matter now, Mum, as if he knew better than she did what sort of material his mother's aggression was made of, and that there are indeed situations when a person has to defend herself even against her own son, otherwise - otherwise she would melt away like the sweet in Mummy's mouth, and at such times one can even strike, indeed, it's better to strike than not to, just as it's better to speak out loud than not to the sentences that come to mind, as if she had never thought them, although they had not come to mind for years precisely because she was always thinking of them. Let these sentences be the lowest points of that dark lake with no surface.

[a vérségi kapcsolat nem elég a közös témához, s hogy nem volna miröl beszélni, ha meggyözödése ellenére nem kérné a fia bocsánatát. S a fia ne oldozza föl, csak annyit mondjon, ha már nagyon szeretne visszafeküdni: most már mindegy, anya, mintha jobban tudná, micsoda anyagból van anyjában ez az agresszió, mint ö maga, s hogy igenis vannak helyzetek, amikor az embernek a fia ellen is meg kell védenie magát, különbenkülönben elenyészik, mint Anyuka szájában a cukor, s olyankor ütni is lehet, söt jobb ütni, mint nem ütni, mint ahogy jobb kimondani, mint nem kimondani azokat a mondatokat, amelyek úgy jutnak az eszébe, mintha soha nem gondolt volna rájuk, holott éppen azért nem jutottak eszébe évekig, mert mindig is ezekre gondolt. Ezek a mondatok legyenek annak a víztükör nélküli tónak a legmélyebb pontjai]. (Szvoren 2010: 20-21)

Violence - both corporeal and linguistic — is an escape at "the lowest points" of signification, where, in the darkness of distancing alienation, all utterances are rendered meaningless unless they perform action. Instead of meaning, it is action that can denote such metaphysical concepts as the soul or redemption in this story. What propels forward Szvoren's narrative is a sustained effort to transpose linguistic functions from telling towards acting, from diegesis towards performatives. Just as there is a shift detectable from communication towards the body, the narrative replaces locution with illocutionary acts. In How to Do Things with Words J. L. Austin defines locutions as "equivalent to uttering a certain sentence with a certain sense" (Austin 1962: 108), whereas illocutionary acts "are utterances which have a certain force" (Austin 1962: 108). To go back to the title of the short story, to offer to be in "pertu" [on intimate terms] with somebody is an illocutionary act. As a kind gesture to allow for informal ways of 
addressing in conversations in Hungarian, it signals the beginning of a close, affectionate, often familial relationship between two persons. This time the sentence the mother says is in direct speech, the identity of the speaker is clear as opposed to the free indirect discourse of her accusation previously cited. "Your father and I thought... that it's high time to switch from the polite to the familiar form of address" [Arra gondoltunk apáddal... legföbb ideje, hogy összetegezödjünk] (Szvoren 2010: 22). After the glasses have clinked, mummy treats her daughter as a puppet: she is jostled around just like a lifeless automaton. A mother switching to the affectionate form of address to her forty-year-old daughter is absurd in itself, yet, furthermore, the breakdown in communication also corroborates that the subject and the agent of this sentence is contextualized in hierarchical power relations. Identity and gender constructions that are created by these suppressive scripts are described in the story with the horror of the following words: "Let a woman be a wound that is identical with the object that caused it" [Legyen a nö olyan seb, ami a sérülést okozó tárggyal azonos] (Szvoren 2010: 20).

As seen from the above, such illocutionary acts also fail to bridge the chasm between parent and child. The ultimate stake of telling this story is hidden in the modality of the text as a question. Is it possible to remove the "object" that becomes identical with the one it subjugates, or else, is it possible to dislocate the subject from power structures embedded in performative speech acts? The answer to these persistent questions lies in the fact that the entire discourse of Szvoren's "On Intimate Terms" is narrated in the imperative mood. There is not one single declarative sentence to be found in the nine-page long narrative of the short story.

The narrative strategy of exclusive reliance on the imperative mood gains its true relevance in contrast to Austin's speech acts. Locutions, perlocutions, illocutions all belong to declarative sentence types incorporating a grammatical subject as a clause element. As emphasized above, all characters as subjects are inevitably determined by the power structures dominating the narrative as its central topic. However, in the case of imperative sentences it is not only the subject that usually remains an empty category, but the identity of the speaker, which is in no linguistic relation with the utterance itself. By way of narrating the events in the imperative mood, the discourse generates a superstructure for the conative function, which wills the possible world into existence, and locates the speaker outside of the discourse, as it is unknown who the speaker is. The emptiness of the speaker's external position creates a chance for gendered identity formations, even if objectified in a landscape, even if kept at a distance. This strategy renders the discourse both metaphysical - in the sense that it refers to an entity outside of language - and corporeal, for the subject of enunciation defines logos as an empty category.

Let God be dead, and the odour of Daddy's mouth noticeable. Let a yellow rocket burst dandelions onto the sky over the housing estate. Let's see before our eyes the green of Modry Kamen, the undulating landscape often described as feminine; let's be homesick for never-seen villages tucked away in the troughs of valleys, dirt paths leading to the Kamenny' vrch, and the blotchy strips of land on the flatland stretching out before Spaní laz.

[Isten legyen halott, Apuka szájszaga érezhetö. Nyiljon sárga rakétapitypang a lakótelep egén. Lássuk magunk elött a Modrý Kameň zöldjét, a táj többnyire nöiesnek nevezett hullámzását, legyen honvágyunk sosem látott falvakat rejtö völgykatlanok, a Kamenný 
Hegyi, Pál. "Distancing Gender in Contemporary Hungarian Fiction.” Hungarian Cultural Studies. e-Journal of the American Hungarian Educators Association, Volume 12 (2019) DOI: 10.5195/ahea.2019.363

vrch-re vezetö földutak és a Španí laz elött elterülö, szántóföldektöl tarka síkság után]. (Szvoren 2010: 22)

Szvoren's distancing gender strategy is marked by an overreliance on the imperative mood, which locates the vantage point of narration outside the discourse. The speaking subject is located outside of the cluster of fixed positions placed within the meta-text of the submissive daughter-oppressive mother script. In consequence, the blaming game hidden in the transparent binaries of abusive gender scripts is laid bare while the conative force of the enunciation is being distributed among an infinite number of positions. Designed to be read as a play script, the imperatives of the short story perform an incessant movement from one authorial position to the absent other, until the existence of the omnipotent point of view is denied all together in the words "Let God be dead" of the concluding section (Szvoren 2010: 22). Even if at a radical distance, in the far-away landscape of a dream-like Slovakia, finally it is made possible by emptying out the subject position in modal detachment to talk about gendered identities ("feminine," "undulating landscape"), emotions ("homesick"), and transcending catharsis ("a yellow rocket burst dandelions onto the sky"), to represent feminity and motherhood ("tucked away") as if in an ekphrasis.

\section{Conclusion}

In the short stories two different narrative strategies were examined to point out how gender, identity, and interpersonal relations may be thematized in a territory created by distancing scripted gender formations. The legacy of relativizing gender formations on the authorial plane is transposed to the level of narration and literary discourse in the works of a new generation of Hungarian authors. Imitation, simulation, and dissemination as strategies geared towards undermining patriarchal gendered codes are limited in their scope by maintaining and reinforcing gendered polarities through switching, crossing, changing between prescribed norms and scripted roles. Just as imitation generates a nostalgic point of origin retrospectively, simulation and dissemination of gendered hierarchies in the above examples are also bound by preexisting binaries of male and female identities. Role-playing games in modernist and postmodernist modes both confront with and build on the context of gendered codes. The insistence of the male gaze gains its power within these works from being unmarked in an asymmetry where the oscillation of role-playing games between two gendered poles are conceptualized within the very same binary. Distancing gender, here, is interpreted as a distinctly different approach that negotiates questions of gendered identities by way of relegating gendered constructions outside of the male-female binary. The two phenomena disclosed two strategies to distance or dislocate performative acts creating gendered identities outside of prescriptivenormative dichotomies. First, Ádám Berta's "Karambol" ['Crash'] with his idiosyncratic handling of characters offered an example for a multiverse of possible worlds within the same discourse. Secondly, Edina Szvoren's short fiction "Pertu" ['On Intimate Terms'] gave a unique example for distancing gender in switching from the indicative mood to the imperative one, a strategy that made gender construction possible by radically emptying out the category and position of the speaking subject. These innovative narratives by eminent prose writers showcase differing strategies how polarities of presupposed modes of writing encoded by both patriarchal scripts and écriture féminine can be dissolved by a renewing interest in the fluidity of gendered constructions in discourses. 
Hegyi, Pál. "Distancing Gender in Contemporary Hungarian Fiction.” Hungarian Cultural Studies. e-Journal of the American Hungarian Educators Association, Volume 12 (2019) DOI: 10.5195/ahea.2019.363

\section{Works Cited}

Austin, John Langshaw. 1962. How to do Things with Words. Oxford: Oxford UP.

Balassa, Péter. 1990. "Minden rendbe' van: Levél és kommentár" ['Everything's Fine: Letter and Commentary']. Jelenkor 33/6: 522-525.

Barthes, Roland. 1974. S/Z: An Essay. New York: Farrar, Straus and Giroux.

Berta, Ádám. 2015. "Karambol” ['Crash']. Kalligram 24/5: 33. http://www.kalligramoz.eu/Kalligram/Archivum/2015/XXIV.-evf.-2015.-majus/KarambolXerxesz-Papa-Joe-napszemuevege-novellak

Bollobás, Enikő. 2010. The Aren't Until I Call Them. Frankfurt am Main: Peter Lang.

Bollobás, Enikő. 2012. "Troping the Unthought: Catachresis in Emily Dickinson's Poetry." Emily Dickinson Journal 21/1: 25-56.

Cristian M., Réka, Dragon Zoltán. 2008. Encounters of the Filmic Kind: Guidebook to Film Theories. Szeged: Szegedi Egyetemi Kiadó.

Culler, Jonathan D. 1983. On Deconstruction: Theory and Criticism after Structuralism. Ithaca: Cornell UP.

Csokonai, Lili [Péter Esterházy]. 1987. Tizenhét hattyúk ['Seventeen Swans’]. Budapest: Magvető kiadó.

Lacan, Jacques. 1998. The Four Fundamental Concepts of Psycho-analysis. London: Vintage. Németh, Zoltán. 2009. "Szerzői név és maszk a magyar posztmodern irodalomban." ['The Author's Name and Mask in Hungarian Postmodern Literature']. Alföld 60:9: 78-84.

Sárbogárdi, Jolán [Lajos Parti Nagy]. 1997. A test angyala ['The Angel of the Body']. Pécs: Jelenkor Kiadó.

Szvoren, Edina. 2009:"Pertu" ['On Intimate Terms']. Holmi 21/10: 1390-1396.

Szvoren, Edina. 2010. “On Intimate Terms.” Translated by Tim Wilkinson. The Hungarian Quarterly 199: 14-22. http://epa.oszk.hu/01000/01050/00070/pdf/holmi_21_10_2009_1390-1404.pdf

Warhol, Robyn R. 1989. Gendered Interventions: Narrative Discourse in the Victorian Novel. New Brunswick and London: Rutgers UP.

Weöres, Sándor [Erzsébet Lónyay]. 1972. Psyché: Egy hajdani költönö írásai ['Psyché: The Writings of a Poetess from the Past']. Budapest: Magvető Könyvkiadó. 